\title{
Physiological effects of major genes affecting ovulation rate in sheep
}

\author{
Kenneth P. McNatTy ${ }^{\mathrm{a} *}$, Susan M. Galloway ${ }^{\mathrm{b}}$, Theresa WILSON ${ }^{\mathrm{b}}$, \\ Peter SMITH ${ }^{\mathrm{a}}$, Norma L. HUDSON ${ }^{\mathrm{a}}$, Anne O'CONNELL ${ }^{\mathrm{a}}$, \\ Adrian H. BIBBY ${ }^{\mathrm{a}}$, Derek A. HEATH ${ }^{\mathrm{a}}$, George H. DAVIS ${ }^{\mathrm{c}}$, \\ James P. HANRAHAN ${ }^{d}$, Jenny L. JUENGEL ${ }^{\mathrm{a}}$ \\ ${ }^{a}$ AgResearch, Wallaceville Animal Research Centre, PO Box 40063, \\ Upper Hutt, New Zealand \\ ${ }^{\mathrm{b}}$ AgResearch, Molecular Biology Unit, Otago University, PO Box 56, Dunedin, New Zealand \\ ${ }^{\mathrm{c}}$ AgResearch, Invermay Agricultural Centre, Private Bag 50034, Mosgiel, New Zealand \\ ${ }^{\mathrm{d}}$ Teagasc, Athenry Research Centre, Athenry, Ireland
}

(Accepted: 26 May 2004 )

\begin{abstract}
Genetic mutations with major effects on ovulation rate in sheep were recently identified in two genes of the transforming growth factor $(T G F \beta)$ superfamily and a $T G F \beta$ receptor, namely bone morphogenetic protein 15 (BMP15), otherwise known as the growth differentiation factor $9 \mathrm{~b}(G D F 9 b), G D F 9$ and activin-like kinase 6 (ALK6) otherwise known as the BMP receptor type IB (BMPRIB). Animals homozygous for the BMP15 or GDF9 mutations are anovulatory whereas animals heterozygous for BMP15 or GDF9 or heterozygous or homozygous for ALK6 have higher than normal ovulation rates. Immunisation of ewes against BMP15 or GDF9 shows that both are essential for normal follicular development and control of ovulation rate. Common features of fertile animals with the BMP15, ALK6 (and possibly $G D F 9$ ) mutations are changes in oocyte development during early preantral follicular growth, earlier maturation of granulosa cells and ovulation of mature follicles at smaller diameters. In summary, these findings have led to a new paradigm in reproductive biology, namely that the oocyte plays a key role in regulating the ovulation rate.
\end{abstract}

genetic mutations / BMP15 / GDF9 / ALK6 / BMPR-IB

\section{INTRODUCTION}

Sheep (Ovis aries) are a highly diverse species with more than 900 different breeds that vary substantially in their physiological characteristics including ovulation rate and fecundity [30]. In some instances, the differences in ovulation rate have been attributed to the action of a single or a closelylinked group of genes [4]. Indeed mutations with major effects on ovulation

\footnotetext{
*Corresponding author: ken.mcnatty@agresearch.co.nz
} 
rate have been identified in two genes of the transforming growth factor beta $(T G F \beta)$ superfamily and a $T G F \beta$ receptor, namely bone morphogenetic protein (BMP15), growth differentiation factor $9 \mathrm{~b}(G D F 9)$ and BMP receptor-IB (ALKO) $[10,11,23,28,33]$. Further mutations in some of these genes or in different genes are likely to be present in other prolific breeds.

The aforementioned gene discoveries have led to a new paradigm in reproductive biology, namely that the oocyte plays a key role in regulating the ovulation rate [10-12]. Thus, sheep are proving to be remarkably informative in offering new insights into why some mammals have a predisposition to produce two or three offspring rather than one [18]. The purpose of this review was to summarise some of the physiological effects of the BMP15, GDF9 and ALK6 mutations affecting ovulation rate in sheep.

\section{THE BMP15 AND GDF9 MUTATIONS}

Five separate point mutations in the BMP15 gene and one point mutation in the GDF9 gene have been identified as affecting the ovulation rate $[2,10,11]$. Animals homozygous for each of these mutations are anovulatory and thus sterile whereas heterozygous animals have mean ovulation rates between 0.8 and 2.4 above that of the respective non-carrier flocks $[5,11]$. Two of the five BMP15 mutations have premature stop codons, one of these ( $\mathrm{FecX} \mathrm{X}^{\mathrm{G}}$ in Belclare and Cambridge sheep) is at amino acid position -29 in the proregion of exon 2 before the mature region thus no mature protein is produced and the other is the Hanna mutation $\left(\mathrm{FecX}^{\mathrm{H}}\right)$ at amino acid 23 of the mature protein rendering it inactive. Another two mutations are nonconservative amino acid substitutions within the mature protein at amino acid positions 31 (Inverdale; FecX $X^{\mathrm{I}}$ ) and 99 (Belclare; FecX ${ }^{\mathrm{B}}$ ). The other identified mutation has been reported in Lacaune ewes and is reported elsewhere in this journal [2]. This mutation was found as a co-dominant mutation in an animal with an autosomal gene affecting ovulation rate. For all mutations, the ovarian phenotypes are indistinguishable in homozygous carriers, in that few, if any, follicles develop beyond the primary (i.e. type 2) stage of development (Fig. 1). The GDF9 mutation (Belclare; $\mathrm{FecG}^{\mathrm{H}}$ ) corresponds to a non-conservative amino acid substitution at position 77 of the mature protein region. The ovarian phenotype in animals homozygous for this mutation is different than that for the BMP15 mutations in that ovarian follicles continue to develop to the antral (i.e. type 5) stages although most, if not all, are abnormal with respect to oocyte morphology and the arrangement and appearance of the granulosa and cumulus cell-types (Fig. 1). 

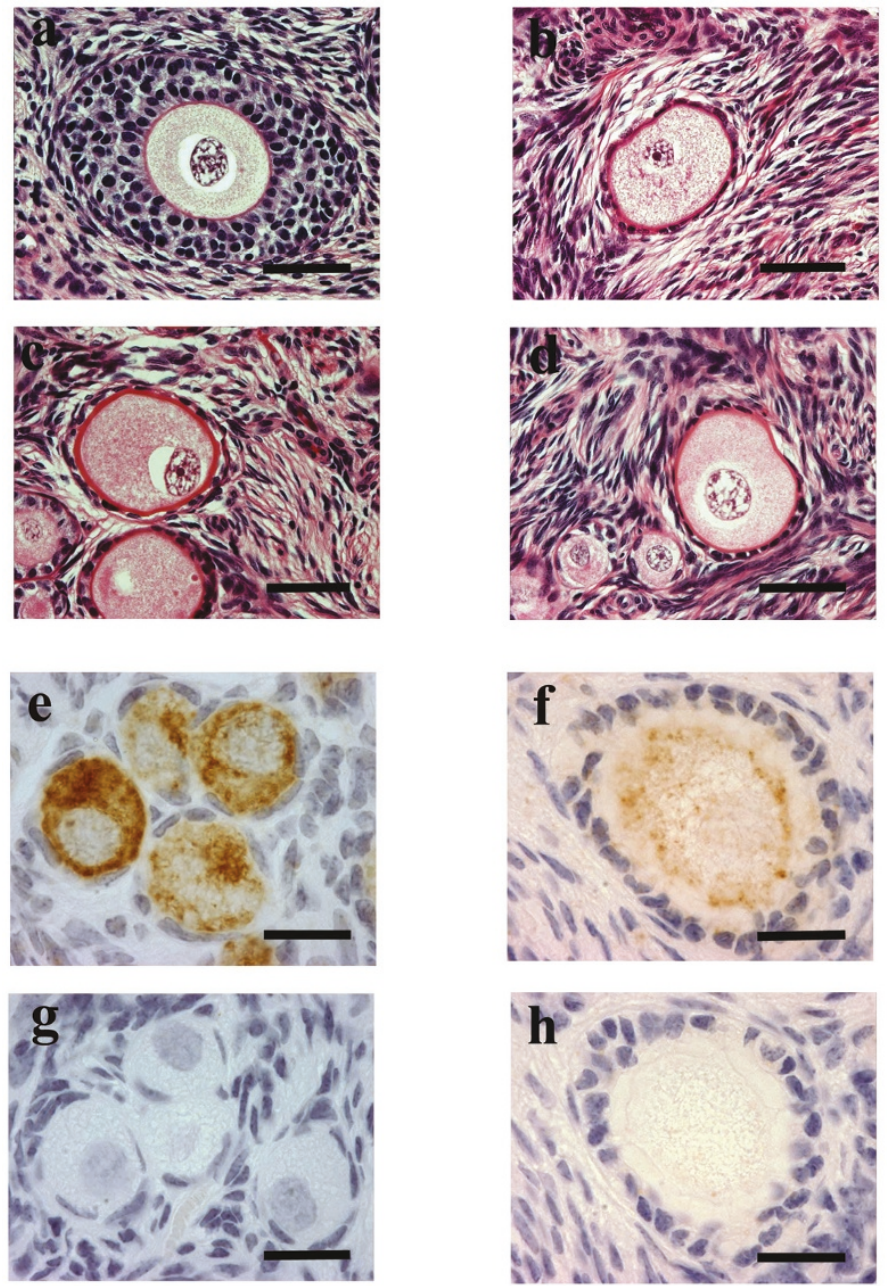

Figure 1. Photomicrographs (a-d) showing normal type 4 (preantral) follicles in a wild-type sheep (a) and abnormal ovarian follicles with similar diameter oocytes $(-80 \mu \mathrm{m})$ in an Inverdale ewe with a homozygous non-conservative aspartic acid substitution for valine at amino acid 31 in BMP15 (b); in a Belclare ewe homozygous for a stop codon at amino residue -29 (i.e. in the proregion of BMP15) (c) and in a Belclare ewe with a homozygous isoleucine substitution for serine at amino acid residue 77 in GDF9 (d). The photomicrographs (e) and (f) show immunostaining for GDF9 and BMP15 in oocytes of type 1 (i.e. primordial) follicles and a type 2 (primary) follicle, respectively, whereas $(\mathrm{g})$ and $(\mathrm{h})$ show the corresponding photomicrographs where the signal has been blocked with an ovine GDF9 peptide or an E. coli derived ovine BMP15 mature protein respectively. The follicles shown in photomicrographs $(\mathrm{e}-\mathrm{h})$ are from normal follicles in wild-type sheep. Scale bars $\mathrm{a}-\mathrm{d}=70 \mu \mathrm{m} ; \mathrm{e}-\mathrm{h}=25 \mu \mathrm{m}$. 
The primary cause of infertility in ewes homozygous for the $B M P 15$ or GDF9 mutations is the apparent lack of bioactive BMP15 or GDF9. These findings are in contrast to those reported for mice [7,34]. GDF9 null mice have been found to be sterile and follicular growth is blocked at the primary stage, whereas in BMP15 null mice, no obvious effects on follicular growth and embryo development have been noted, although some defects in fertilisation have been observed. In the heterozygous mice, no differences in ovulation rate have been reported. To explain this paradox, Liao et al. [15] suggest that this might be due to altered intracellular processing and secretion of BMP15 and GDF9 because of the nature of the mutations in sheep and of the way in which the mouse BMP15 gene is mutated by deleting the entire second exon. These authors produced a recombinant human BMP15 with an amino acid substitution at position 31 which mimics the mutation in Inverdale sheep. They found that a mutant dimerised form of BMP15 can be secreted from a cell line that does not contain a GDF9 expression system. However, when the mutant form of $B M P 15$ is co-expressed with $G D F 9$, the proteolytic processing and secretion of $B M P 15$ is inhibited and the secretion of GDF9 is impaired. It was proposed that the mutations in the BMP15 gene in sheep may actually affect the level of GDF9 secretion and that abnormal concentrations of GDF9 are the cause of the Inverdale phenotype. However, when sheep are immunised against peptides specific for BMP15 or GDF9, the evidence is that secreted forms of BMP15 as well as GDF9 are essential for both normal follicular development and ovulation rate $[12,18]$.

\subsection{The BMP15 and GDF9 immunisation experiments}

The purpose of the immunisation experiments in sheep was to test whether extracellular concentrations of GDF9 or BMP15 are important for the regulation of follicular development and ovulation rate. To test this, the ewes were immunised at monthly intervals for 7 months with keyhole limpet haemacyanin (KLH) or KLH conjugated with an E. coli derived mature BMP15 protein or with a 15 mer $G D F 9$ or $B M P 15$ peptide respectively in Freunds adjuvant. The major effects on ovarian phenotype are a significant reduction in ovarian volume, no normal follicular development beyond the type 2 stage, few, if any type 5 (i.e. antral) follicles and significantly larger oocytes in the type 2-4 follicles in both the BMP15 and GDF9 groups [12]. This phenotype is similar to that observed in sheep with the BMP15 and GDF9 mutations. Passive immunisation of ewes with $B M P 15$ or GDF9 specific antibodies during the follicular phase of the oestrous cycle showed that both factors are also 
essential during the preovulatory follicular maturation. In follow-up studies, where ewes were given a primary and booster injection of KLH or bovine serum albumin (BSA) conjugated to the BMP15 or GDF9 peptide, in a waterbased adjuvant, significant increases in mean ovulation rates of around 0.4 to 1.2 were achieved relative to the KLH or BSA immunised controls [13] (McNatty, Juengel, unpublished data). These findings suggest that a partial neutralisation of BMP15 or GDF9 in biological fluid leads to an ovulation response similar to those observed in animals with the heterozygous mutations of either BMP15 or GDF9 [10,11]. While these studies show that both GDF9 and $B M P 15$ are essential for follicular growth and ovulation rate, they do not rule out the possibility that some of their effects are due to the presence of BMP15/GDF9 heterodimers.

\subsection{Intraovarian sites of $B M P 15$ and $G D F 9$ gene expression and possible mechanisms of action}

Within the sheep ovary, $B M P 15$ and GDF9 are expressed exclusively by the oocyte (Fig. 2). Both GDF9 mRNA and protein are present in normal sheep oocytes in non-growing type 1 follicles (i.e. primordial follicles) as well as in growing follicles $[3,12]$ (Fig. 1). In contrast, BMP15 mRNA and protein are both present from the type 2 (i.e. primary) stage (Fig. 2). With respect to receptors for the $T G F \beta / \mathrm{BMP}$ ligands, $B M P R-I I$, activin receptor-like kinase 6 (ALK6), ALK3, and ALK5 mRNA are present in oocytes at all stages of follicular growth [1,29,33] (Fig. 2; Juengel, unpublished data). In granulosa cells, $B M P R-I I$ and $A L K 3$ are present at all stages including type 1 follicles, whereas $A L K 6$ is present from the type 2 stage and $A L K 5$ from the type 4 stage of growth. In theca interna cells, BMPR-II, ALK3, ALK5 but not ALK6 are present from the type 4 stage of growth [1,32] (Fig. 2). However, a low level of ALK6 protein has been detected in theca by immunohistochemistry suggesting that this receptor might be present [29]. In rats, $B M P 15$ binds to $A L K 6$ with very little affinity for $A L K 3$ and $B M P R-I I$ inhibits $B M P 15$ induced cell functions [22] suggesting that cells expressing both $A L K 6$ and BMPR-II are probable targets for the $B M P 15$ ligand. If this holds true for sheep, then it is likely that granulosa cells and the oocyte are affected by oocyte-derived BMP15 from the type 2 stage of growth [33]. In rat granulosa cells, GDF9 is known to bind to $B M P R-I I$ [32] and to stimulate inhibin A and B production via the Smad2 pathway [26] inferring that the type 1 receptor might be an activin or TGF $\beta$ receptor rather than $A L K 3$ or $A L K 6$ [24]. Indeed a recent report shows that $A L K 5$ (TGFRRI) is the type 1 receptor for GDF9 [19]. This finding suggests that GDF9 could have autocrine effects on the oocyte from the type 1 stage and paracrine effects on both the granulosa and theca cells from the type 4 (range 


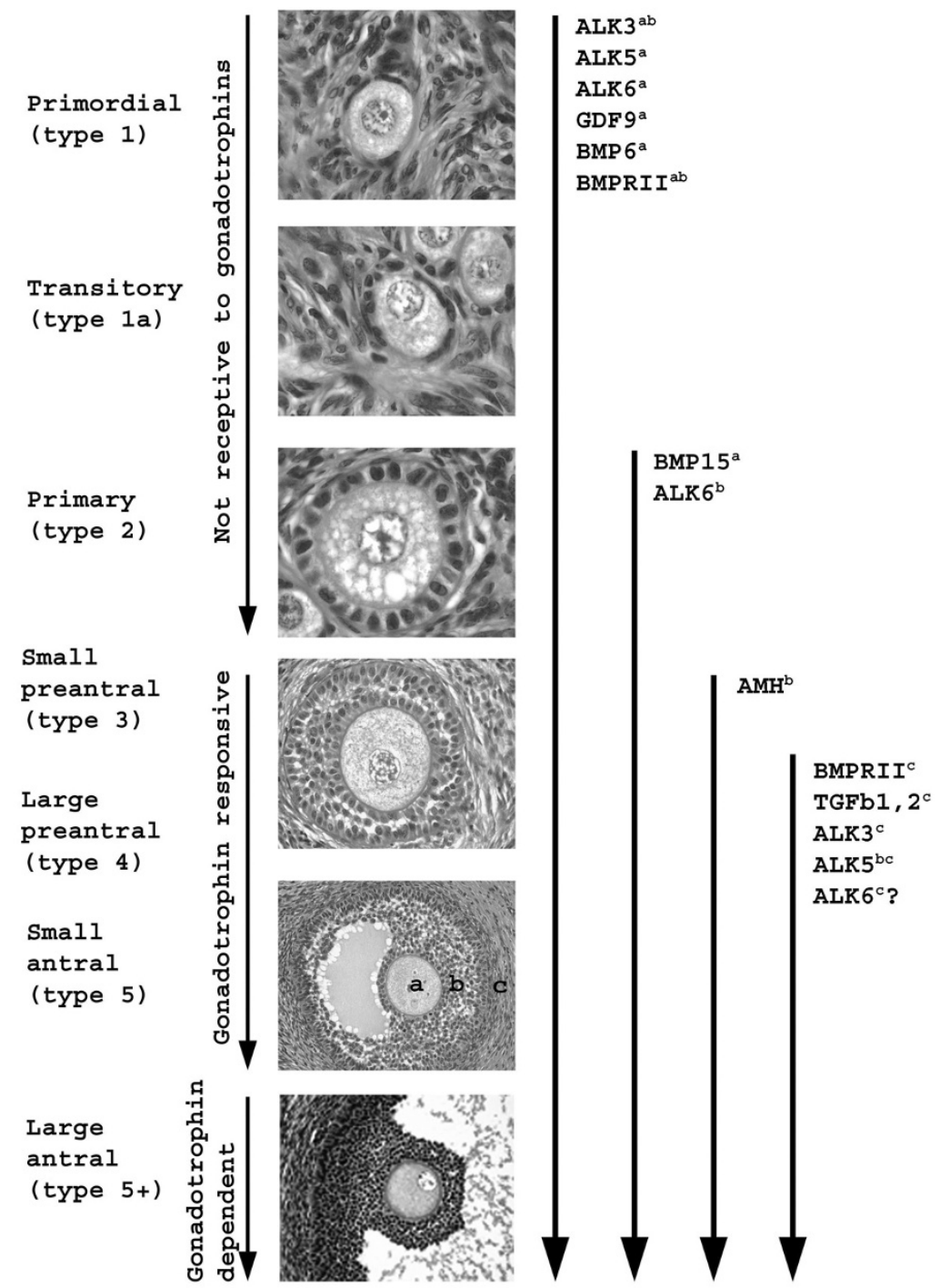

Figure 2. Onset of expression of GDF9, BMP15, BMP6 and receptors of the TGF $\beta$ superfamily with respect to the stage of ovarian follicular development and responsiveness to pituitary gonadotrophins. The superscripts $\mathrm{a}, \mathrm{b}$ and $\mathrm{c}$ refer to the oocyte, granulosa cells and theca interna respectively. GDF9, growth differentiation factor 9, $B M P 15$, bone morphogenetic protein $15, B M P 6$, bone morphogenetic protein 6 , $T G F \beta$, transforming growth factor beta, $B M P R I I, B M P$ receptor type II, $A L K 5$, activinlike kinase 5 (otherwise known as TGFBRI or TGF beta receptor type 1), ALK3 (otherwise known as BMPRIA), ALK6 (otherwise known as BMPRIB), AMH, anti-Mullerian hormone. ALK6? infers that some uncertainty remains as to whether this gene is expressed in theca cells (see text). Modified from Montgomery et al. [20]. 
preantral) stage of growth. It is worth noting that GDF9 mRNA and protein are present before follicular formation in sheep as well as in non-growing type 1 follicles in several species including sheep, cows and possum $[3,8,12]$. Thus, either the form of the protein is biologically inactive, the appropriate receptors are not present on the adjacent granulosa cells in type 1 follicles or that GDF9 is a relatively inactive growth factor when other companion factors are absent.

The roles of GDF9 and BMP15 as assessed from in vitro studies appear complex with some possible species differences. In rodents, both BMP15 and GDF9 stimulate proliferation of cultured granulosa cells from antral follicles, whereas in sheep only recombinant ovine BMP15 has been shown to induce modest proliferation [25,31] (McNatty, unpublished data). An explanation for the higher ovulation rate observed in heterozygous Inverdale or Hanna ewes has been offered by Shimasaki and his colleagues [25] based on their in vitro findings that BMP15 may reduce the sensitivity of granulosa cells to FSH by inhibiting expression of the FSH receptor. Thus, in animals such as the heterozygous Inverdale or Hanna with a lower than normal concentration of $B M P 15$, a higher FSH-induced granulosa cell responsiveness would result. In granulosa cells from heterozygous Inverdale ewes, a higher FSH-induced cAMP responsiveness has been observed relative to wild-type animals in the absence of any differences in the plasma concentrations of FSH, LH or ovarian steroids [27]. Since GDF9 has also been shown in rats to inhibit FSH-induced cAMP synthesis [31], the overall effect of the GDF9 mutation in sheep may be to enhance the sensitivity of the ovarian follicle to FSH and thereby increase the ovulation rate in a manner similar to that noted for BMP15.

\subsection{The ALK6 (BMPR-IB) mutation}

The ALK6 mutation was first identified in Booroola ewes (FecB) as a point mutation at nucleotide position 830 leading to an arginine replacing a glutamine amino acid (i.e. Q249R) in a highly conserved region of the intra cellular kinase domain [23, 28,33]. The dominant phenotype is precocious ovarian follicular development [20] and exceptional prolificacy [4]. Some significant secondary effects have been observed in Booroola sheep, most likely because ALK6 mRNA is present in a wide range of tissues as well as the ovaries, including the brain, pituitary, kidneys, skeletal muscle, uterus and prostate and testes [20,33]. ALK6 mRNA is also likely to be expressed in several tissues during fetal development such as the heart and mesonephros [17]. The evidence for effects of the Q249R ALK6 mutation in various tissues during fetal development as well as on pituitary function and ovarian follicular formation 
have been summarised elsewhere [20]. As reported by Davis [4], the Booroola (Q249R $A L K-6$ ) mutation has now been identified in a number of different sheep breeds throughout the world.

The ALK6 knockout mouse does not display the same phenotype as the Booroola ewe [36]. ALK6 knockout mice appear to have normal ovarian follicular development and ovulation rates although there is a reduction in fertility perhaps caused by the failure of normal cumulus expansion. Unlike Booroola sheep, ALK6 null mice exhibit defects in chondrogenesis leading to defects in skeletal development [35]. In two unrelated human families, point mutations have been identified in the ALK6 gene [14]. In one family, the mutation resulted in a lysine residue substituting for an isoleucine (I200K) in a region of ALK6 involved in phosphorylation of the receptor. In the other family, a tryptophan is substituted for an arginine (R486W) in a highly conserved region of the C-terminal of the ALK6 kinase domain. These mutations cause malformations in limb development but there are no reports of effects on fertility. Experiments to block the actions of putative ligands interacting with the $A L K 6$ receptor in sheep or mutating the $A L K 6$ receptor in mice to generate the Booroola mutant have not been reported. Thus, comparisons of the ALK6 mutation in sheep with the $A L K 6$ knockout mice to explore mechanistic interpretations of species differences in ovulation rate are premature.

\subsection{Intraovarian effects of $A L K 6$ expression and possible mechanisms of action}

ALK6 together with BMPR-II mRNA have been identified in ovine oocytes of type 1 follicles and expression levels for both remain high throughout the follicular types 1-4 and early type 5 stages of growth [37] (Fig. 2). Thereafter, the levels of $A L K 6$ but not BMPR-II mRNA in oocytes decline in large antral follicles [33]. Both ALK6 and BMPR-II mRNA are also present in granulosa cells from the type 2 stage of growth but little or no ALK6 is detectable in theca interna cells (Fig. 2). It seems likely that there is a functional interaction between BMP15 and ALK6 since the effect on the ovulation rate is multiplicative in Booroola Inverdale crossed sheep that are heterozygous for the ALK6 and BMP15 mutations [6]. Moreover, it has been shown that the $B M P$ but not the $T G F \beta 1$ or activin A signalling pathway is altered in granulosa cells from carriers of the Q249R ALK6 mutation [9,21]. Given that BMP6 and $B M P 15$ were expressed in ovine oocytes from the type 1 and 2 stages respectively (Fig. 2; Juengel, unpublished data), it is reasonable to expect that one or 
Table I. Relationships between the granulosa cell numbers and follicular diameter with respect to the Booroola genotype before, at and after an inflection point ${ }^{\dagger}$. Values are means \pm s:e.m.

\begin{tabular}{cccc}
\hline Genotype & $\begin{array}{c}\text { Follicular types 2-5 } \\
\text { slope pre-inflection } \\
(b)\end{array}$ & $\begin{array}{c}\text { Ln Inflection point, } \\
\mu \mathrm{m}(d)\end{array}$ & $\begin{array}{c}\text { Initial slope plus } \\
\text { change in slope } \\
\text { post-inflection } \\
(b+g)^{\dagger}\end{array}$ \\
\hline++ & $2.68 \pm 0.03$ & $7.11 \pm 0.04$ & $1.57 \pm 0.08$ \\
BB & $2.87 \pm 0.05^{* *}$ & $6.46 \pm 0.06^{* *}$ & $2.05 \pm 0.08^{* *}$ \\
\hline
\end{tabular}

$\dagger$ For each of the genotypes $(\mathrm{BB}=$ homozygous carriers of the Booroola gene; ++ homozygous non-carriers of the Booroola gene) the model fitted was: Ln (granulosa cell number $)=a+b$ Ln (follicular diameter $)+g[(\mathrm{Ln}$ follicular diameter $-d) \times(\mathrm{Ln}$ follicular diameter $>d$ )], where $a=$ intercept, $b=$ initial slope of Ln (granulosa cell number) against $\mathrm{Ln}$ (follicular diameter), $d=$ the inflection point along the $\mathrm{Ln}$ (follicular diameter) axis and $g$ is the change in slope from the initial slope to the final slope after the inflection point (unpublished data). **For each column, $P<0.01$.

both of these intrafollicular ligands would interact with the BMPR-II/mutant $A L K 6$ complex $[10,11]$ to affect some change in oocytes or granulosa cells in early growing follicles and this appears to be the case. In animals that are homozygous carriers and non-carriers for the Booroola mutation, oocytes reach their mature diameter of $\sim 130 \mu \mathrm{m}$ at the types 4 and 5 stages of development respectively [33]. This divergence between the genotypes in diameters of the oocytes is already evident at the type 3 follicular stage. Changes in granulosa cell numbers with respect to follicular diameters (e.g. 75 to $\geq 3000 \mu \mathrm{m}$ ) have also been examined after fitting a broken stick regression model (i.e. 2 straight lines with an inflection point) for each genotype (see Tab. I). The results from analyses of the granulosa cell populations from the type 2 to type 5 stages of development show that the Booroola mutation influences granulosa cell development both before as well as after antrum formation [16] (Tab. I). In preantral follicles, the granulosa cells accumulate in greater numbers with respect to follicular diameter in BB compared to ++ ewes until follicles reach a $639 \mu \mathrm{m}$ diameter. Thereafter in ++ ewes, the granulosa cells continue to accumulate as beforehand until the follicles reach a $1224 \mu \mathrm{m}$ diameter. Once $\mathrm{BB}$ and ++ follicles reach the aforementioned respective diameters, the accumulation of granulosa cells with respect to follicular diameter changes but it continues to remain higher in the BB genotype (Tab. I). However follicles in $\mathrm{BB}$ ewes reached an ovulatory size at $-3000 \mu \mathrm{m}$ diameter and in ++ ewes 
between 5000 and $6000 \mu \mathrm{m}$ diameter with the mean numbers of granulosa cells per preovulatory follicle being 1.9 million and $\sim 5$ million, respectively. These differences in oocyte and granulosa cell development in sheep with the Q249R ALK6 mutation are associated with a significantly higher FSH-induced cAMP responsiveness and earlier onset of follicular steroidogenesis including earlier onset of aromatase activity in granulosa cells, together with an earlier onset of LH responsiveness in the granulosa cells (for a review, see [20]). All of these events in the ALK6 mutated ewes lead to maturation and ovulation of multiple ovarian follicles at smaller follicular diameters without any changes in the ovarian secretion rates of steroid or inhibin during either the follicular or luteal phases of the oestrous cycle [20]. These results when taken together with those from Fabre et al. (2003) [9] suggest that some intraovarian factors have antidifferentiative roles (e.g. anti-luteinising effects) on ovine granulosa cells and that one important consequence of the mutated ALK6 receptor is a decreased ability of some BMP to inhibit differentiation. It remains to be determined how specific BMP act on the BMPR-II complexes and how the downstream signalling pathways of the mutated $A L K 6$ receptor influences cell function in Booroola sheep.

\section{CONCLUSION}

A common feature of the BMP15 and ALK6 mutations is that changes in oocyte are evident during early preantral (i.e. type 3 ) development followed by precocious follicular maturation with each preovulatory follicle containing a reduced population of granulosa cells. Although not proven, the same characteristics are likely to be true for sheep with the GDF9 mutation. The immunisation studies show that both GDF9 and BMP15 are essential for follicular development in sheep but it remains to be determined whether GDF9 and BMP15 act as heterodimers and whether these growth factors either separately or together exert their effects through the $A L K 6$ receptor. In summary, these data suggest new possibilities for developing novel therapeutic reagents for regulating fertility in mammals.

\section{ACKNOWLEDGEMENTS}

The authors wish to thank the NZ Foundation for Research Science and Technology, the NZ Marsden Fund and Ovita Ltd., for financial support for this project and Leanne Still and Lynn O’Donovan for histology support. 


\section{REFERENCES}

[1] Bibby A.H., Reader K.L., Lun S., McNatty K.P., Juengel J.L., The role of the transforming growth factor $\beta$ (TGF $\beta$ ) during ovarian follicular development in sheep, 12th annual Queenstown molecular biology meeting, 1-4 September 2002, Queenstown, New Zealand.

[2] Bodin L., Lecerf F., Pisselet C., SanCristobal M., Bibé B., Mulsant P., How many mutations are associated with increased ovulation rate and litter size and progeny of Lacaune meat sheep?, in: Proc. Workshop on Major Genes and QTL in Sheep and Goat, Toulouse, France, 8-11 December 2003, CD-ROM.

[3] Bodensteiner K.J., Clay C.M., Moeller C.L., Sawyer H.R., Molecular cloning of the ovine growth/differentiation factor-9 gene and expression of growth/differentiation factor-9 in ovine and bovine ovaries, Biol. Reprod. 60 (1999) 381-386.

[4] Davis G.H., Major genes affecting ovulation rate in sheep, Genet. Sel. Evol. 37 (Suppl. 1) (2005) S11-S23.

[5] Davis G.H., Bruce G.D., Dodds K.G., Ovulation rate and litter size of prolific Inverdale $\left(\mathrm{FecX} \mathrm{X}^{\mathrm{I}}\right)$ and Hanna $\left(\mathrm{FecX}^{\mathrm{H}}\right)$ sheep, in: Proc. Association for the Advancement of Animal Breeding and Genetics, 14 (2001) 175-178.

[6] Davis G.H., Dodds K.G., Bruce G.D., Combined effect of the Inverdale and Booroola prolificacy genes on ovulation rate in sheep, in: Proc. Association for the Advancement of Animal Breeding and Genetics, 13 (1999) 74-77.

[7] Dong J., Albertini D., Nishimori K., Kumar T.R., Lu N., Matzuk M.M., Growth differentiation factor-9 is required during early ovarian folliculogenesis, Nature 383 (1996) 531-535.

[8] Eckery D.C., Whale L.J., Lawrence S.B., Wylde K.A., McNatty K.P., Juengel J.L., Expression of mRNA encoding growth differentiation factor 9 and bone morphogenetic protein 15 during follicular formation and growth in a marsupial, the brushtail possum (Trichosurus vulpecula), Mol. Cell. Endocrinol. 192 (2002) 115-126.

[9] Fabre S., Pierre A., Pisselet C., Mulsant P., Lecerf F., Pohl J., Monget P., Monniaux D., The Booroola mutation in sheep is associated with an alteration of the bone morphogenetic protein receptor-IB functionality, J. Endocrinol. 177 (2003) 435-444.

[10] Galloway S.M., McNatty K.P., Cambridge L.M., Laitenen M.P.E., Juengel J.L., Jokiranta T.S., McLaren R.J., Luiro K., Dodds K.G., Montgomery G.W., Beattie A.E., Davis G.H., Ritvos O., Mutations in an oocyte-derived growth factor (BMP15) cause increased ovulation rate and infertility in a dosage-sensitive manner, Nat. Gen. 25 (2000) 279-283.

[11] Hanrahan J.P., Gregan S.M., Mulsant P., Mullen M., Davis G.H., Powell R., Galloway S.M., Mutations in the genes for oocyte derived growth factors GDF9 and BMP15 are associated with both increased ovulation rate and sterility in Cambridge and Belclare sheep (Ovis aries), Biol. Reprod. 70 (2004) 900-909. 
[12] Juengel J.L., Hudson N.L., Heath D.A., Smith P., Reader K.L., Lawrence S.B., O’Connell A.R., Laitinen M.P.E., Cranfield M., Groome N.P., Ritvos O., McNatty K.P., Growth differentiation factor 9 and bone morphogenetic protein 15 are essential for ovarian follicular development in sheep, Biol. Reprod. 67 (2002) 1777-1789.

[13] Juengel J.L., Hudson N.L., Whiting L., McNatty K.P., Effects of immunization against BMP15 and it GDF9 on ovulation rate, fertilization and pregnancy in ewes, Biol. Reprod. 70 (2004) 557-561.

[14] Lehmann K., Seemann P., Stricker S., Sammar M., Meyer B., Suring K., Majewski F., Tinschert S., Grzeschik K.H., Muller D., Knaus P., Nurnberg P., Mundlos S., Mutations in bone morphogenetic protein receptor IB cause brachydactyly type A2, Proc. Natl. Acad. Sci., USA 100 (2003) 12277-12282.

[15] Liao W.X., Moore R.K., Otsuka F., Shimasaki S., Effect of intracellular interactions on the processing and secretion of bone morphogenetic protein-15 (BMP-15) and growth and differentiation factor-9: Implication of the aberrant ovarian phenotype of BMP-15 in mutant sheep, J. Biol. Chem. 278 (2003) 3713-3719.

[16] McNatty K.P., Lun S., Heath D.A., Ball K., Smith P., Hudson N.L., McDiarmid J., Gibb M., Henderson K.M., Differences in ovarian activity between Booroola X Merino ewes which were homozygous, heterozygous and non-carriers of a major gene influencing their ovulation rate, J. Reprod. Fertil. 77 (1986) 193-205.

[17] McNatty K.P., Smith P., Hudson N.L., Heath D.A., Tisdall D.J., O W.-S., Braw-Tal R., Development of the sheep ovary during fetal and early neonatal life and the effect of fecundity genes, J. Reprod. Fertil. (Suppl. 49) (1995) 123-135.

[18] McNatty K.P., Juengel J.L., Wilson T., Galloway S.M., Davis G.H., Hudson N.L., Moeller C.L., Cranfield M., Reader K.L., Laitinen M.P.E., Groome N.P., Sawyer H.R., Ritvos O., Oocyte derived growth factors and ovulation rate in sheep, Reproduction (Suppl. 64) (2003) 1-13.

[19] Mazerbourg S., Klein C., Roh J., Kaivo-Oja N., Mottershead D.G., Korchynskyi O., Ritvos O., Hsueh A.J., Growth differentiation factor9 (GDF9) signalling is mediated by the type 1 receptor ALK5, Mol. Endocrinol.18 (2004) 653-665.

[20] Montgomery G.W., Galloway S.M., Davis G.H., McNatty K.P., Genes controlling ovulation rate in sheep, Reproduction 121 (2001) 843-852.

[21] Monget P., Fabre S., Mulsant P., Lecerf F., Elsen J.M., Mazerbourg S., Pisselet C., Monniaux D., Regulation of ovarian folliculogenesis by IGF and BMP system in domestic animals, Domest. Anim. Endocrinol. 23 (2002) 139-154.

[22] Moore R.K., Otsuka F., Shimaska S., Molecular basis of bone morphogenetic protein-15 signaling in granulosa cells, J. Biol. Chem. 278 (2003) 304-310.

[23] Mulsant P., Lecerf F., Fabre S., Schibler L., Monget P., Lanneluc I., Pisselet C., Riquet J., Monniaux D., Callebaut I., Cribiu E., Thimonier J., Teyssier J., 
Bodin L., Cognie Y., Chitour N., Elsen J.M., Mutation in bone morphogenetic protein receptor-IB is associated with increased ovulation in Booroola ewes, Proc. Natl. Acad. Sci., USA 98 (2001) 5104-5109.

[24] Otsuka F., Yao F., Lee Th., Yamamoto S., Erickson G.F., Shimasaki S., Bone morphogenetic protein-15: Identification of target cells and biological functions, J. Biol. Chem. 275 (2000) 39523-39528.

[25] Otsuka F., Yamamoto S., Erickson G.F., Shimasaki S., Bone morphogenetic protein-15 inhibits follicle-stimulating hormone (FSH) action by suppressing FSH receptor expression, J. Biol. Chem. 276 (2001) 11387-11392.

[26] Roh J.S., Bondestam J., Mazerbourg S., Kaivo-Oja N., Groome N., Ritvos O., Hsueh A.J.W., Growth differentiation in factor-9 stimulates inhibin production and activates Smad 2 in cultured rat granulosa cells, Endocrinology 144 (2003) 172-178.

[27] Shackell G.H., Hudson N.L., Heath D.A., Lun S., Shaw L., Condell L., Blay L.R., McNatty K.P., Plasma gonadotrophin concentrations and ovarian characteristics in Inverdale ewes that are heterozygous for a major gene $\left(\mathrm{FecX}^{I}\right)$ on the $\mathrm{X}$ chromosome that influences ovulation rate, Biol. Reprod. 48 (1993) 1150-1156.

[28] Souza C.J.H., MacDougall C., Campbell B.K., McNeilly A.S., Baird D.T., The Booroola $(\mathrm{FecB})$ phenotype is associated with a mutation in the bone morphogenetic receptor type IB (BMPRIB) gene, J. Endocrinol. 169 (2001) R1-R6.

[29] Souza C.J., Campbell B.K., McNeilly A.S., Baird D.T., Effect of bone morphogenetic protein 2 (BMP2) on oestradiol and inhibin A production by sheep granulosa cells and localization of BMP receptors by immunohistochemistry, Reproduction 123 (2002) 363-369.

[30] Terrill C.E., The distribution of breeds as related to domestication and development of modern genotypes, in: Foote W.C., Bunch D.T. (Eds.), The domestication of sheep; their ancestors, geography, time period and people involved, Proceedings of a Workshop by The International Sheep and Goat Institute, Utah State University, Logan, 1979, pp. 41-112.

[31] Vitt U.A., McGee E.A., Hayashi M., Hsueh A.J., In vivo treatment with GDF9 stimulates primordial and primary follicle progression and theca cell marker CYP17 in ovaries of immature rats, Endocrinology 141 (2000) 3814-3820.

[32] Vitt U.A., Klein C., Hseuh A.J., Bone morphogenetic protein receptor type II is a receptor for growth differentiation factor-9, Biol. Reprod. 67 (2002) 473-480.

[33] Wilson T., Wu X.Y., Juengel J.L., Ross I.K., Lumsden J.M., Lord E.A., Dodds K.G., Walling G.A., McEwan J.C., O’Connell A.R., McNatty K.P., Montgomery G.W., Highly prolific Booroola sheep have a mutation in the intracellular kinase domain of bone morphogenetic protein IB receptor (ALK-6) that is expressed in both oocytes and granulosa cells, Biol. Reprod. 64 (2001) 1225-1235. 
[34] Yan C., Wang P., De Mayo J., De Mayo F.J., Elvin J.A., Carino C., Prasad S.V., Skinner S.S., Dunbar B.S., Dube J.L., Celeste A.J., Matzuk M.M., Synergistic roles of bone morphogenetic protein 15 and growth differentiation factor 9 in ovarian function, Mol. Endocrinol. 15 (2001) 854-866.

[35] Yi S.E., Daluiski A., Pedersen R., Rosen V., Lyons K.M., The type 1 BMP receptor BMPRIB is required for chondrogenesis in the mouse limb, Development 127 (2000) 621-630.

[36] Yi S.E., LaPolt P.S., Yoon B.S., Chen J.Y.L., Lu J.K.H., Lyons K.M., The type 1 BMP receptor Bmpr IB is essential for female reproductive function, Proc. Natl. Acad. Sci., USA 98 (2001) 7994-7999.

[37] Wilson T., Wu X.Y., Juengel J.L., Ross I.K., Lumsden J.M., Lord E.A., Dodds K.G., Walling G.A., McEwan J.C., O’Connell A.R., McNatty K.P., Montgomery G.W., Highly prolific Booroola sheep have a mutation in the intracellular knase domain of bone morphogenetic protein IB receptor (ALK-6) that is expressed in both oocytes and granulosa cells, Biol. Reprod. 64 (2001) 1225-1235.

To access this journal online: www.edpsciences.org 